Department of Economics

\author{
WORKING PAPER \\ $8 / 2015$
}

\title{
An Empirical Analysis of Hunting Lease Pricing and Value of Game in Sweden
}

\author{
Justice Tei Mensah, Katarina Elofsson
}

Economics

Working Paper Series 2015:07

Uppsala 2015 
SLU $\begin{aligned} & \text { Sveriges lantbruksuniversitet } \\ & \text { Swedish University of Agricultural Sciences } \\ & \text { Department of Economics }\end{aligned}$

\begin{abstract}
Hunting generates considerable benefits to hunters, while simultaneously causing damages to agriculture and forestry. The aim of this paper is to estimate hunting values for multiple hunted species, by disentangling the role of wildlife harvesting opportunities from other factors which affect hunting lease prices. We examine the determinants of hunting lease prices in Sweden using both spatial and non-spatial econometric techniques. Our analysis confirms considerable hunting values for large ungulates such as moose and fallow deer. Results also suggest that hunters prefer to have a diverse set of ungulate species on their hunting ground. Moreover, the study reveals the presence of spatial spillovers in lease prices, implying that landowners have little scope for exerting monopoly power on the lease market. It also indicate that proximity to urban centers, income, size of the hunting field, and congestion cost are key drivers of hunting lease prices.
\end{abstract}




\section{Introduction}

Wildlife plays an integral role in the socioeconomic wellbeing of people around the world through the provision of hunting opportunities. Hunting is a popular activity undertaken by millions of people around the world, and associated benefits are multiple, including meat, recreation, and cultural and religious values. In many advanced economies, particularly in Scandinavia, recreational hunting is popular and hunters spend a significant amount of income and time on hunting (Fredman et al., 2010, Lundhede et al., 2015). In Sweden for example, there are an estimated 300,000 hunters and each hunter spends an average of 20 days per annum on hunting (Boman et al., 2011, Ericsson et al., 2010). The total gross hunting value in Sweden is estimated to be in the neighborhood of 3 billion SEK per annum (Mattson et al., 2008).

The importance of hunting is not restricted to hunters, the sale of hunting leases and fees also generates significant revenues to landowners (Lundhede et al., 2015). Moreover, hunting is important to farmers and forest owners as a means for keeping wildlife populations under control in order to reduce browsing damages to agriculture and forests. On the other hand, wildlife conservationist sometimes oppose hunting as it is feared that hunting threatens the survival of animal populations.

The presence of different stakeholders with varying interests brings to fore the need for policies to regulate hunting activities optimally. The development of wildlife policies, which contribute to society's welfare, requires knowledge about the economic benefits generated by different game, as well as knowledge about the functioning of markets for hunting related activities. Knowledge about hunting lease prices is also of relevance to landowners in evaluating the benefits of measures to improve a hunting field or analyzing the tradeoff between the increasing wildlife populations vis-àvis the cost of associated wildlife damages (Lundhede et al., 2015).

Given that hunting is to large extent a recreational activity, the economic values are not fully reflected in market prices (Boman et al., 2011) and the properties of the markets are not well known. It is therefore necessary to employ the relevant economic techniques to estimate such values and identify market properties.

Empirical studies on economic valuation of game are relatively scant, and the extant studies vary in their choice of valuation method. The two main methods used in valuation are the revealed preference and stated preference approaches. The revealed preference approach infers economic values of an activity based on observed behavior of economic agents in an actual market. The travel cost and hedonic price methods are the two most applied revealed preference methods for the valuation of game species (Livengood,1983; Knoche and Lupi, 2012, 2013). These revealed preference approaches measure use values, i.e., values associated with active utilization of the resource such as meat value and recreational value of hunting. For instance, Livengood (1983) estimates the value of deer hunting in the United States using the hedonic price method to be 450 
SEK per deer in 2011 prices. Using the travel cost method, Knoche and Lupi (2012) also estimates the value of deer hunting in the United States to be between 580- 620 SEK ${ }^{1}$.

Stated preference methods, on the other hand, value non-market goods by eliciting consumer preferences directly using hypothetical markets. The approach measures both use and non-use economic values, with contingent valuation and choice experiment as the most widely used methods in valuation of wildlife (eg. Boman and Mattsson, 2012, Boman et al., 2011, Horne and Petäjistö, 2003). For instance, Boman et al. (2011) used the contingent valuation method to analyze hunting values for moose in Sweden by comparing values obtained from two datasets, 1987 and 2006. Results from the study revealed a significant increase in moose hunting value per unit of hunting effort over the period. Also, in a comprehensive review of the benefits and costs of wildlife species, Häggmark-Svensson et al. (2015) observe that the value recreational hunting ranges between 58 and $3520 \mathrm{SEK} /$ hunting day. In spite of the differences in the methodological approach, these studies reveal significant economic values attributed wildlife species.

The aim of this paper is to estimate the economic value of game species to hunters by disentangling these values from other factors which affect hunting lease prices. To achieve this goal, a hedonic price model is used to estimate the demand for hunting leases in Sweden, and from this model marginal implicit hunting values are estimated. We note that the available literature on hedonic price model for hunting leases is silent on the possible spatial dynamics in the hunting lease prices. Meanwhile, recent advances in the literature on hedonic price models in general suggest that amenity prices often tend to be spatially correlated (Brasington and Hite, 2005). This suggests that accounting for such spatial interactions is important towards obtaining robust estimates. In line with the above, this paper contributes to and refines the extant literature on hunting leases and economic valuation of game by demonstrating the effects of spatial spillovers in lease prices on the estimated implicit hunting values.

Findings indicate that large ungulates such as moose and fallow deer hunting have high economic values in Sweden. Our results also suggest that even though hunters prefer game diversity, preference is higher for ungulate species relative to wild boars. There are significant spatial spillovers in the equilibrium hunting lease prices across municipalities, implying that the scope for landowners to exert monopoly power in the market is limited. Further, we observe that factors such as proximity to urban areas, income and forest share of hunting area are significant factors driving equilibrium hunting lease prices in the study area.

In the section that follows, we present a brief overview of the institutional structure of hunting in Sweden. In section 3, the theoretical basis of the paper is presented, while section 4 gives a description of the empirical model estimated. In sections 5, we present and discuss the findings of the paper. Conclusions and implications for policy are discussed in section 6 .

\footnotetext{
${ }^{1}$ All prices unless specified are measured using 2011 as base year
} 


\section{The hunting lease market in Sweden}

The Swedish hunting market includes both long-term leases of hunting land, typically on an annual basis or for several years, and short-term leases on a daily or weekly basis. The long term leases dominate the market, and short-term leases are only offered on a smaller scale by large landowners such as large forest companies, the church, and municipalities. Generally, a long-term lease implies that the landowner grants a group of hunters the right to hunt all species on the land. For most species, the hunter group is free to decide on the harvesting strategy, as long as wildlife damage to agricultural and forest crops are held within reasonable limits (Ministry of Industry, 1997). Moose hunting is however, an exception; here hunting is required by law to be coordinated across larger so called moose management areas, where hunters, landowners and representatives of the county administration jointly decide on harvesting strategies (Sandström et al., 2013).

Hunting groups and hunting lease prices are typically very stable over time (Ericsson et al., 2010, Ministry of Industry, 1997). When there are free places within a hunting team, these places are usually filled with relatives and friends. Large forest companies also sometimes offer hunting leases to employees, or on the basis of waiting lists. Less than one percent of the hunters have found their hunting land on an open market through advertising or tenders (Ministry of Industry, 1997).

In a twice repeated survey of hunting lease prices among large Swedish landowners, large forest companies, the church, municipalities and manors, it is concluded that majority of respondents believe that higher game availability, more game diversity, and proximity to urban areas imply higher lease price, whereas the presence of established carnivore populations, large roads, and unsuitable land consolidation implies lower lease prices (Lönnqvist, 2011, Sandström et al., 2013).

\section{Theory}

In this section we present a simple static model analyzing the interplay between two representative agents: the landowner and the hunter, in determining equilibrium hunting lease prices. We follow Palmquist (1989) in first analyzing each agent's optimization problem in the absence of the lease market. This permits us to identify determinants of bid and offer prices. The exposition focusses on the role of wildlife and wildlife harvest for the hunting lease price.

\section{Landowner's problem}

We assume a representative landowner who utilizes his land for agriculture and/or forestry. The landowner's net returns from agriculture and forestry in the absence of wildlife is assumed to be $\pi^{0}$. The stock of wildlife on the land, $W$, gives rise to costs for wildlife damage, $c_{d}(W)$, to agriculture, forestry and land quality due to browsing and burrowing, respectively. The landowner is assumed to maximize returns from land use activities such as agriculture and forestry, less the cost of damages caused by wildlife population, and consequently, the profit function of the landowner can be specified as: 
$\pi=\pi^{0}-c_{d}(W)$

where $\partial c_{d} / \partial W \geq 0$ and $\partial^{2} c_{d} / \partial W^{2} \geq 0$

Given the naturally determined size of the wildlife population in the absence of harvest, $W^{0}$, the actual stock of wildlife, $W$, is determined by the size of the harvest, $H$, and can be expressed as:

$W=f\left(H ; W^{0}\right)$

where $\partial W / \partial H<0$, i.e. a higher harvest rate reduces wildlife population on the land (Clark, 2010). Using the relation in equation (2), equation (1) can be rewritten in terms of harvests as

$\pi=\pi^{0}-c_{d}(f(H))$

such that $\partial \pi / \partial H=-\left(\partial c_{d} / \partial W\right)(\partial W / \partial H) \geq 0$. Therefore, given $W^{0}$, the landowner's profit increases with harvest, as harvesting reduces the cost of damages on his land. An increase (decrease) in $W^{o}$ would shift the marginal cost function, $c_{d}^{\prime}(f(H))$, to the right (left), but is assumed to have no impact on the slope.

Further, we assume that the landowner cannot directly affect the wildlife population $W$, but can only do this indirectly by selling hunting leases to the hunter. The landowners offer price function for the hunting lease can then be expressed as:

$\sigma=\sigma\left(H ; W^{0}, z, \kappa, \tau\right)$

Equation (4) states that the offer price is defined by the harvest rate, given the exogenously determined wildlife population, and a set of other exogenous factors such as plot characteristics, z, and a vector of landowner and hunter specific characteristics, denoted by $\kappa$ and $\tau$, respectively . The landowner's preferred hunting rate is that which reduces the wildlife population to zero. Thus in principle, the landowner's maximum offer price would be negative, i.e. he would be willing to pay the hunter for hunting, and hence reducing wildlife and the damages which it causes, as long as the payment does not exceed the wildlife damage cost. However, the harvest rate agreed upon by the landowner and the hunter will not only be determined by the landowner's offer price, but also by hunter's bid price, via bargaining. The agreed harvest is therefore likely to differ from the landowner's preferred level, and the agreed price is also likely to differ from the landowner's maximum offer price. 


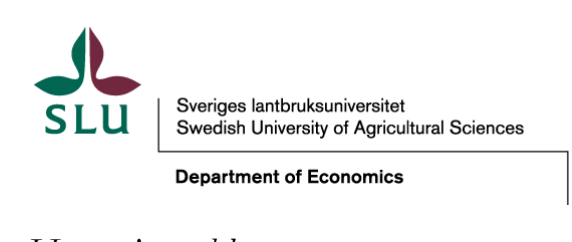

\section{Hunter's problem}

We define the hunter's production technology as a Schaefer harvest function (Schaefer, 1957) expressed as:

$$
H=q E W
$$

where $E$ is the effort level and $q$ is a catchability coefficient, which is determined by the hunting technology applied. The hunter's decision problem can be expressed as:

$$
B=b(H)-c(E)
$$

where $b(H)$ is the gross hunting benefit while $c(E)$ is the cost of hunting effort. Hunting benefits here consist of meat and recreational value as well as the net present value of wildlife population for future harvest. The effort cost on the other hand is composed of explicit and implicit costs of hunting. Explicit cost include among other things, the cost of hunting equipment and provision of feeding plots for the wildlife; while implicit cost here refers to the opportunity cost of hunting time such as forgone wage income and recreational activities.

The amount of effort devoted to hunting will increase up to the point where the marginal product effort is equal to the marginal effort cost:

$$
\partial B / \partial E=(\partial b / \partial H)(\partial H / \partial E)-\partial c / \partial E=0
$$

where the first term on the right hand side is the marginal product of effort and positive, whereas the last term is the marginal cost of hunting effort, with $\partial c / \partial E \geq 0$. Using equation (5), the marginal condition (7) can also be written in terms of harvest as:

$$
\partial B / \partial H=\partial b / \partial H-(\partial c / \partial E)(\partial E / \partial H)=0
$$

where $\partial B / \partial H \geq 0$ and $\partial E / \partial H \geq 0$. This is the hunter's privately optimal harvest rate. The first term on the right hand side of equation (8) is the marginal benefit of harvest while the second term is the marginal cost of harvest. A change in the exogenous initial population, $W_{0}$, results in a shift in the hunter's marginal benefit function, $b^{\prime}(H)$, but with no effect on the slope and the marginal cost function. Therefore an increase (decrease) in $W_{0}$ increases (decreases) the hunter's privately optimal harvest rate.

With this in mind, the hunter's bid function can be expressed as: 


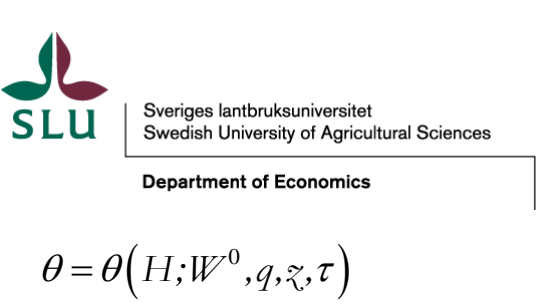

The hunter's bid price is thus determined by the agreed harvest rate, given initial wildlife population, the catchability coefficient of wildlife, and a set of plot and hunter specific characteristics. The maximum amount the hunter is prepared to pay for the lease, is the net benefit from hunting at that the agreed level of harvesting.

The equilibrium lease price is determined by the equality between the bid and offer functions such that $\theta\left(H ; W^{0}, z, q, \tau\right)=\sigma\left(H ; W^{0}, z, \tau, \kappa\right)=R\left(H^{*} ; W^{0}, q, z, \tau, \kappa\right)$ where $R=R(\cdot)$ is the lease price function, with $H^{*}$ representing the contracted or agreed harvest level.

\section{Special cases}

Finally, until now we have assumed that wildlife actually gives rise to damages to the landowner and that there are net benefits from hunting to the hunter, at least up to a certain level. This is likely to hold for species such as moose and fallow deer (Boman et al., 2012). However, this assumption may not always hold. We will therefore look at three special cases:

Case I: Wildlife that causes no damage, but has a positive hunting value

If wildlife does not cause any damage, the landowner is indifferent to the harvest level, but still willing to lease his land to hunters for a positive lease price. Given scarcity of hunting opportunities, hunters are willing to pay for leasing the land. Hence, lease prices are determined on the market by supply and demand for hunting plots with different attributes (Palmquist, 1989). Thus, both agents are price takers, and the market price operates to ensure that excess in demand and supply for hunting plots with each set of attributes are eliminated, via price adjustments (Palmquist, 1989).

Case II: Zero or negative net hunting value

In some cases, the marginal benefit of hunting can be less than the marginal cost of effort, such that $(\partial b / \partial H)(\partial H / \partial E)<\partial c / \partial E$. This can occur when both the wildlife in question has a low or even zero meat and recreational value, i.e., $\partial b / \partial H$ is low; when the catchability coefficient is small, implying a low $\partial H / \partial E$; or cost of effort is high, i.e. $\partial c / \partial E$ is large. In this case, the hunter has no private incentive to hunt, and in the absence of compensation he will prefer $H=0$. If the damages of wildlife are significant, the landowner will then have to pay the hunter to hunt, and the payment will increase in the harvest levels. Our model depicts the case with a single wildlife species, but in the presence of multiple species, where just one of those fulfils the condition of having a negative net hunting value, a higher harvest of that species can be expected to be associated with a lower offer price for the hunting lease and consequently a lower lease price. 
Case III: Positive wildlife existence value to the landowner

So far we have examined the optimal decisions facing the two agents leading to the determination of the equilibrium lease price. Implicit in the analysis is the assumption of zero existence value of wildlife to the landowner. Positive existence values imply that the landowner will prefer to have wildlife on his land as long as the marginal existence value exceeds the marginal damage cost (Rollins et al., 2004, Yoder, 2000). This would increase the landowner's offer price, and within the framework presented above, positive existence values would have a similar impact as a reduction in the wildlife damage cost function.

\section{Methodology, Data and Study Area}

This section presents a description of the empirical model and the estimation procedure. Data used for the study are also discussed.

\section{Empirical model}

The hedonic model is one of the key techniques in measuring non-use values especially environmental amenities (Rosen, 1974). A plethora of literature on the real estate market exist which employed the hedonic approach in measuring the influence of environmental amenities in the determination of housing prices. The hedonic approach is a revealed preference valuation technique primarily used in estimating demand for quality differences in consumer goods and economic values of environmental attributes (Livengood, 1983). In this study, we estimate the determinants of hunting lease prices and their associated implicit prices within the framework of the hedonic price model. We specify our empirical model as a reduced form model of the equilibrium land rent obtained from equating the bid and offer functions in equations (5) and (9) respectively as shown in equation (10).

$$
\begin{aligned}
\ln P_{i t}= & \alpha+\beta_{1} \ln Y_{i t}+\beta_{2} \ln H_{i t}+\beta_{3} \ln \text { Fshare }_{i t}+\beta_{4}\left(\ln \text { Fshare }_{i t}\right)^{2}+\beta_{5} \ln D_{i t}+\beta_{6} \ln A_{i t}+\beta_{7} \ln R_{i t} \\
& +\beta_{8} \ln F_{i t}+\beta_{9} \ln M_{i t}+\beta_{10} \ln B R_{i t}+\beta_{11} O w n+\beta_{12} D I_{i t}+\varepsilon_{i t}
\end{aligned}
$$

where $P_{i t}$ refers to the average lease price (per hectare) paid by hunting team in municipality $i$ at time $t ; Y_{i t}$ is the average income of members in the hunting group; $H_{i t}$ is the average number of hunters in a group purchasing the lease- a measure of congestion effect (Conlin et al., 2009); $D_{i t}$ is the distance of the field to the nearest large city. It has been observed that generally, prospective hunters without access to their own hunting fields but willing to pay for a lease to a hunting ground are mostly located in the urban centers (Rhyne et al., 2009). As a result, the distance of the hunting field from the city is expected to influence how many hunters compete for the lease, and hence aggregate demand. Thus a negative nexus is hypothesized, since longer distances from the city imply higher travel cost which translates into reduced demand for hunting leases, hence lower price. The 
parameter $A_{i t}$ captures the size of the lease plot, and it could be expected that a larger plot is associated with a higher price given the larger likelihood of a successful hunt. The parameter Fshare $_{i t}$ relates the proportion of the field that is forested. Even though forest provides a suitable biome for wild species, the ecological literature suggest that many species benefit from the presence of a combination of different habitats types; and habitat variation could increase the number of species present since some species do not prefer the dense forest whiles others do. For instance, Meilby et al. (2006), observe that there is higher preference for lands with more diverse vegetation by both hunters and wildlife as diversity creates niches for different wildlife. As a result, open forests are conducive for hunting and aesthetic purposes (Meilby et al., 2006). Thus, we assume the relationship between forest shares and lease prices has an inverted U-shape. The intuition is that there is some threshold level of forest shares beyond which wildlife abundance and hence lease prices may fall. Further, we represent $R_{i t}, F_{i t}, M_{i t}$ and $B R_{i t}$ as respectively the number of roe deer, fallow deer, moose and wild boar harvested on plot $i$ at time $t$. We control for differences in the land ownership through an ownership dummy $(O w n)$, where $O w n=1$ for commercial/public ownership and $O w n=0$ if otherwise. We also complement the model with a game diversity index to test the hypothesis that hunters prefer game variety in a prospective hunting area. Results from Hussain et al. (2010), Munn et al. (2011) and Rhyne et al. (2009) suggest that game diversity has a positive and significant influence on hunters' willingness to pay for hunting leases. Both landowners and hunters can be expected to prefer deer and moose over wild boars. For the landowner, the reason is the land damages associated with the wild boar due to their burrowing activities. For instance, the Swedish Board of Agriculture estimates wild boar damages to be around 140 SEK per hectare ${ }^{2}$ (Clarin and Karlsson 2010). For the hunter, wild boar hunting is associated with comparatively low catchability, as the species is elusive, and only active in the night, as well as a comparatively high cost of effort, as hunting typically require building costly carrions, having a night vision rifle scope, and hunting in nighttime, where the latter could be associated with a considerable opportunity cost. Therefore as a test for this claim, we construct an additional diversity index exclusive of wild boars.

\section{Empirical strategy}

A survey through the literature on hedonic pricing models reveals that amenity values are often influenced by spatial spillover effects (Brasington and Hite, 2005). For example, trends in lease market in municipality $i$ might have spillover effects on markets in adjoining municipalities and vice versa. This is because, when a given land is put on the lease market, its offer price is set within the knowledge of lease price(s) of other hunting grounds in the neighborhood. In the same way, bid prices are influenced by bids on neighboring lands (Brasington and Hite, 2005). This observation is consistent with the assumption of our theoretical model that agents are price takers. Thus, estimating a hedonic model such as equation (10), without controlling for possible spatial effects might lead to spurious results. Hence the need to control for such effects.

\footnotetext{
${ }^{2}$ In 2011 prices
} 
The empirical approach of this study is summarized as follows. First, we estimate the model outlined in equation (10) using the non-spatial pooled OLS. Relevant robustness checks are conducted. Also, to account for heterogeneity across the time period, time fixed effects are applied in the estimation ${ }^{3}$. However, as indicated earlier, the pooled OLS approach is unable to account for the effects of spatial interactions in the model estimated. Hence, as a second step, we test for possibility of any spatial effects in the model using the Moran's tests for spatial autocorrelation. The confirmation of spatial autocorrelation provides basis for proceeding to estimate a spatial panel hedonic price model using the Spatial-Autoregressive with Spatially Auto-correlated Errors Model (SAC/SARAR). Results from both models (OLS versus SAC) are then compared to see the effects of accounting for spatial effects in the model on the parameter estimates. As a final step, the marginal implicit values are estimated to determine the marginal willingness to pay (WTP) to hunt for each animal considered. The resulting WTP estimates constitute the hunters' economic valuation of hunting one unit of each respective animal.

Spatial-Autoregressive with Auto-correlated Errors Model (SAC/SARAR)

Spatial effects in hedonic pricing models can occur via two channels: first, through amenity prices, whereby prices of an amenity in neighboring localities can exert upward or downward pressure on the price of the same amenity in a particular location. Secondly, when certain unobserved factors or omitted variables that affect amenity prices are correlated over space. This results in spatially correlated residuals. Therefore to account for these two possible channels of spatial autocorrelation in a model simultaneously, the SAC model has been proposed.

This model implicitly is a combination of the spatial-lag model (SAR) and the spatial error model (SEM). On the one hand, the SAR model assumes that, for instance, lease price of a particular hunting field is not only determined by the standard explanatory variables/characteristics of the hunting field and the neighborhood attributes i.e. direct effects per se, but in addition, is influenced by the weighted average of the lease price in the neighborhood or region, i.e. indirect effects(Won Kim et al., 2003). On the other hand, SEM assumes that the error terms of the hedonic price equation are spatially correlated, due to the omitted variables that are spatially correlated (Won Kim et al., 2003). Such spatially correlated errors may occur due to measurement errors in the variables (Anselin and Bera, 1998).

Thus, the SAC model assumes spatial autocorrelation in both the dependent variable and error terms. Also, the SAC model is a fairly general model in the sense that it allows for spatial spillovers in the endogenous and exogenous variables as well as the residuals. The mathematical representation of the SAC model can be expressed as:

$$
\begin{aligned}
& y=\lambda W_{1} y+X \beta+\varepsilon \\
& \varepsilon=\rho W_{2} \varepsilon+\mu
\end{aligned}
$$

\footnotetext{
${ }^{3}$ Estimating individual fixed effects using the current data was not possible due to the large cross section $(\mathrm{N}=54)$ and small time period $(T=2)$.
} 
where $y$ is the dependent variable; $X$ and $\beta$ represent respectively, a vector of explanatory variables and their associated estimated coefficients; $W_{1} y$ represents the spatially weighted dependent variable (lease price). Its associated coefficient, $\lambda$, the spatial autoregressive parameter, measures the extent to which prices in one area is affected by the prices in neighboring communities. This may also be interpreted as an information effect, in the sense that if hunters are unsure of the appropriate lease value of a particular plot given its attributes, they may infer from the value of neighboring plots (see: Jensen et al., 2014). The term $\rho$ is the coefficient of the spatially weighted error terms. It measures the effect of spatially correlated omitted variables in the model. Estimating equation (11) via the maximum likelihood approach imposes the assumption of normally distributed error terms $(\varepsilon \square N(0, \sigma))$. $W_{1}$ and $W_{2}$ denote the weighting matrices associated with the spatial lag process and spatial error process respectively (Murray and Simcos 2003). In this study the same weighing matrix is used for both processes as commonly done in the literature.

Constructing the spatial weight matrix can be done using the contiguity, k-nearest neighbors, or the inverse-distance approach. However, as argued by Anselin (1988), there is no formal approach in deciding the choice of the weighting matrix. Therefore, in this study, weighting matrices were constructed using the k-nearest neighbors and contiguity approaches. Results presented herein, are based on weights generated from the contiguity approach as it was shown to be the most robust ${ }^{4}$. Detailed exposition on the construction of the weighting matrix and estimation of spatial regressions are not discussed in the present study. Interested readers may refer to Anselin (1988), (1998), Drukker (2009), and Millo and Piras (2012).

\section{Implicit Prices}

From an estimated hedonic price function, implicit prices (IMP) for each attribute (regressor) can be computed by taking the partial derivative of the hedonic price function with respect to the attribute. However this result depends largely on the functional form of the estimated model. For instance, from equation (10), the implicit marginal price associated with the explanatory variables expressed in logs (eg. the log of the harvest of roe deer) is computed ${ }^{5}$ as (Hussain et al., 2010, McMillan et al., 1980, Stewart, 2005):

$$
I M P_{R}=\hat{\beta}_{7}\left(\frac{P}{R}\right)
$$

\footnotetext{
${ }^{4}$ Results from the k-nearest neighbor matrix can be presented upon request.

${ }^{5}$ For instance given the function: $\operatorname{Ln} P=\alpha+\beta \ln X+\phi Y$, the partial derivative of the function with respect to $\mathrm{x}$ and $Y$ can be expressed respectively as: $\frac{\partial P}{\partial X}=\frac{\partial e^{(\alpha+\beta \ln X+\phi Y)}}{\partial X}=\beta\left(\frac{P}{X}\right)$ and $\frac{\partial P}{\partial Y}=\frac{\partial e^{(\alpha+\beta \ln X+\phi Y)}}{\partial Y}=\phi(P)$
} 
Thus, the implicit price associated with an attribute $R$ is equal to the product of the associated parameter estimate and the ratio of the dependent variable $P$ and the attribute $R$ evaluated at their respective means.

For explanatory variables expressed in levels (eg. proportion of field that is forested), the associated implicit prices are also expressed as:

$$
I M P_{f s}=\hat{\beta}_{3}(P)
$$

Whereas for explanatory variables (eg. private ownership) expressed in discrete form (dummy variables), their implicit prices are computed as (Cho et al., 2010, Hussain et al., 2010, McMillan et al., 1980, Stewart, 2005):

$$
\frac{\partial y}{\partial O w n}=\left(e^{\beta_{11}}-1\right) \times 100
$$

However, it must be emphasized that the above approach for estimating implicit prices does not apply to spatial models as the coefficients of regressors does not capture the impact of a change in the independent variable on the dependent variable. To interpret the SAC model (11), we first express the model in its reduced form as:

$$
y=\left[I-\lambda W_{1}\right]^{-1} X \beta+\varepsilon ; \quad \varepsilon=\rho W_{2} \varepsilon+\mu,
$$

where $\left[I-\lambda W_{1}\right]^{-1}$ is an $(n \times n)$ inverse matrix, $I$ is an identity matrix, whiles all other parameters and variables remains as previously defined. Thus from equation (15), the impact estimates (partial derivatives) can be expressed as

$$
\frac{\partial y}{\partial X^{\prime}}=\beta\left[I-\lambda W_{1}\right]^{-1}
$$

The expression in (16) constitutes the total impact of a change in any of the independent variables on the dependent variable. The total impact is the sum of the direct and indirect (induced) impacts. The direct impact estimate measures the effect of a change in an explanatory variable in neighborhood $i$ on the dependent variable in the same neighborhood. The indirect impact however, captures the effect of a change in an independent variable on the dependent variable in neighborhood $j(\forall j \neq i)$. Thus equation (16) suggest that a marginal change in lease prices will trigger a ripple effect in the hunting lease market, affecting prices of neighboring plots and their neighbors and so forth. 
Thus, in the context of this study, by estimating equation (10) via the SAC model, the marginal implicit prices associated to say, roe deer harvest, in the log-log specification can be expressed as:

$$
I M P_{R}=\hat{\beta}_{7}\left[I-\lambda W_{1}\right]^{-1}\left(\frac{P}{R}\right)
$$

\section{Data and Study Area}

This study uses secondary data on hunting lease prices, land characteristics, socioeconomic characteristics of hunting groups, etc., from 54 municipalities in Sweden during the period 20102011. Data on hunting lease prices, land characteristics, ownership, size of hunting team, and roe and fallow deer harvest were collected through telephone interviews with chairs of 70 local hunting organizations belonging to the Swedish Hunters Association ${ }^{6}$. The survey was carried out in March and April 2013, and all subjects but one responded. The dataset includes only hunting lease prices paid by hunters that hunt locally. Hence, we do not need to take into account that prices can differ depending on whether the hunting ground is leased by local inhabitants or people living further away. All hunting leases included are on an annual basis, as is common practice for most land in Sweden. Complementary data on average annual income on municipality level was collected from Statistics Sweden, and data on average wild boar and moose harvests on municipality level were obtained from Wildlife Data (viltdata.se). The distance to the nearest big city was calculated as the distance from the major urban center in the municipality to the nearest of the three largest Swedish cities; Stockholm, Gothenburg and Malmö. Due to paucity of spatial data at the plot level, our data for the analysis averaged up to municipality level. The implicit assumption herein is that hunting groups are homogenous in each municipality.

The game harvest diversity index was calculated using the Shannon-Weaver diversity index. This index proposed by Shannon and Weaver (1949) is a mathematical measure of species diversity in a given area. It is expressed as:

$$
H=-\sum_{i=1}^{s} p_{i} \ln p_{i}
$$

where $p_{i}$ measures the proportion of individuals of species $i$ to the total the number of individuals of all species, and $s$ is the total number of species. The higher the index, the greater the degree of species diversity and vice versa. This measure of diversity is beneficial for the relative ease of computation, but it is also known to be sensitive to changes in rare species, i.e., less abundant species.

Fig. 1 shows the map of the municipalities considered in the study. Descriptive statistics of the variables used in this paper are summarized in Table 1. Also a correlation matrix of the variables is provided in the appendix (table A2). The rule of thumb is that multicollinearity is present when the

\footnotetext{
6 The local hunting organizations can, in a relatively straightforward manner, be associated with municipalities.
} 
Variance Inflation Factor (VIF) exceeds 5 or 10, which corresponds to a correlation coefficient of 0.9 or higher. The results in the matrix show the absence of a possible multicollinearity in the model since none of the correlation coefficient is close to 0.9. Further robustness checks are undertaken to ascertain the presence or otherwise of heteroscedasticity. As shown in table 2, the Bruesh and Pagan test is insignificant across the various specifications, thereby signifying the absence of heteroscedasticity in the estimated model(s).

Table 1. Descriptive statistics

\begin{tabular}{lcccc}
\hline Variable & Mean & Std. Dev. & Min & Max \\
\hline Lease price (SEK per ha.) & 124 & 49.27 & 59.5 & 325 \\
Average size of a hunting field/hectares & 860.37 & 751.92 & 75 & 4000 \\
Commercial/pub ownership & 0.31 & 0.47 & 0 & 1 \\
Distance to nearest (big) city/km & 127.41 & 72.38 & 17.60 & 322 \\
Average annual income (1000) SEK & 270.56 & 22.14 & 232.80 & 380.3 \\
Average Number of hunters in a team & 9.24 & 8.20 & 1 & 50 \\
Forest share (\%) & 66.77 & 26.65 & 0 & 100 \\
Roe deer harvest & 6.57 & 6.97 & 0 & 30 \\
Fallow deer harvest & 4.37 & 10.27 & 0 & 48 \\
Wild boar harvest & 84.32 & 134.63 & 0 & 725.58 \\
Moose harvest & 0.72 & 1.12 & 0 & 5.11 \\
Game diversity index (all animals) & 0.41 & 0.34 & 0 & 1.22 \\
Game diversity index (excl. wild boar) & 0.29 & 0.24 & 0 & 0.87 \\
\hline
\end{tabular}


Fig. 1. Map of selected municipalities used in this study

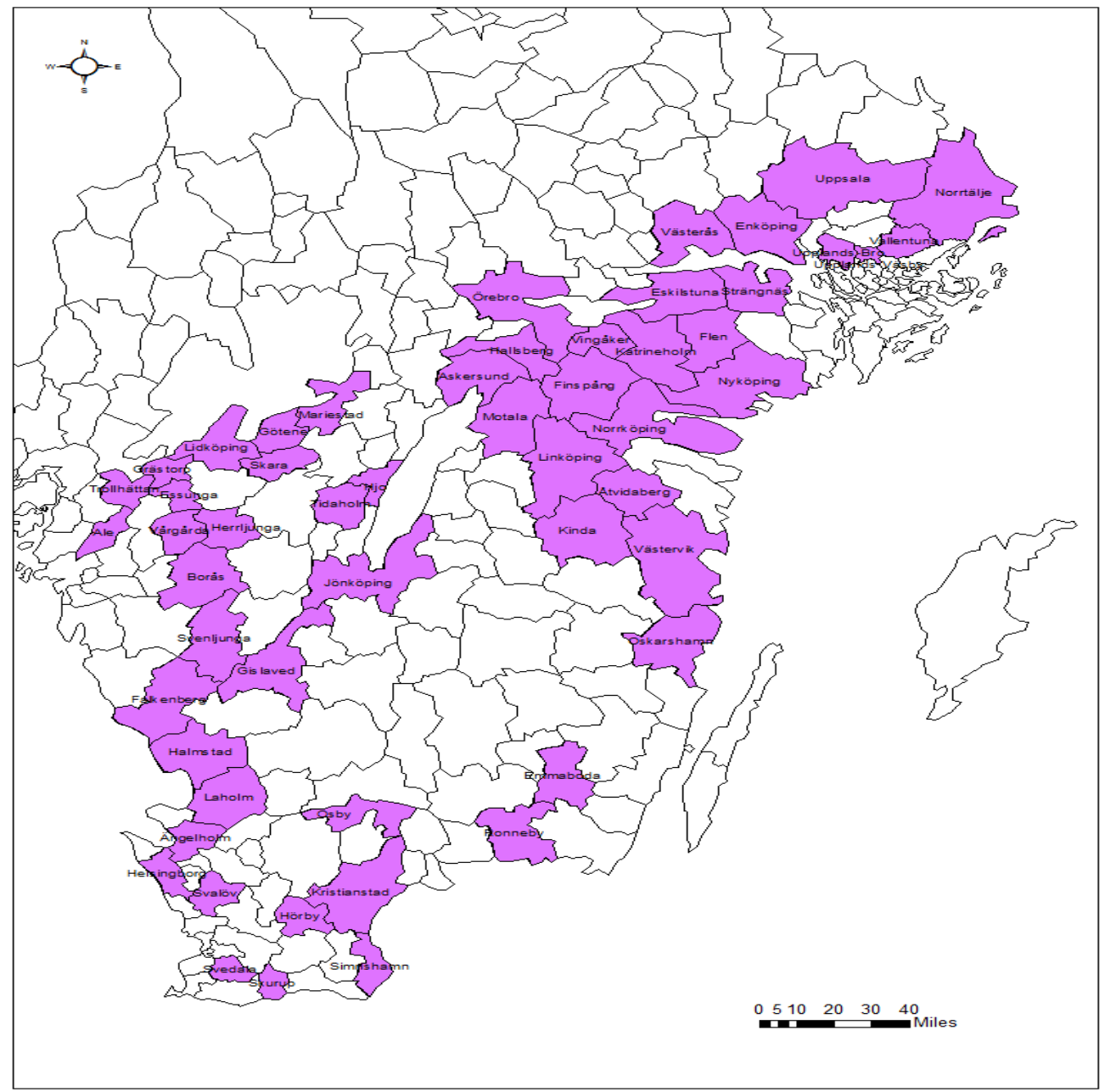

\section{Empirical Results and Discussion}

Our point of departure in this section is the estimation of the hedonic price model via a non-spatial panel model (pooled OLS) approach; analyze the spatial effects of the lease prices and to further estimate a spatial panel model (SAC) upon identification of spatial spillovers. As a contribution to the literature, parameter estimates from the two models are compared to examine the effects of accounting spatial interactions in the model on the estimation outcome. However, it must be emphasized that since our main focus is in analyzing the robust (spatial) model, we do not provided detailed analysis on the results of the pooled OLS estimates. 
Table 2. Pooled OLS estimates

\begin{tabular}{|c|c|c|c|c|c|c|c|c|c|c|}
\hline VARIABLES & $(1)$ & $(2)$ & (3) & (4) & (5) & $(6)$ & $(7)$ & $(8)$ & (9) & $(10)$ \\
\hline log of size of hunting field & $\begin{array}{l}0.090^{*} \\
(0.047)\end{array}$ & $\begin{array}{l}0.088^{*} \\
(0.046)\end{array}$ & $\begin{array}{l}0.086^{*} \\
(0.045)\end{array}$ & $\begin{array}{c}0.065 \\
(0.053)\end{array}$ & $\begin{array}{c}0.039 \\
(0.047)\end{array}$ & $\begin{array}{c}0.075 \\
(0.047)\end{array}$ & $\begin{array}{c}0.061 \\
(0.050)\end{array}$ & $\begin{array}{l}0.086^{*} \\
(0.046)\end{array}$ & $\begin{array}{c}0.043 \\
(0.053)\end{array}$ & \\
\hline Commercial/pub ownership & $\begin{array}{c}0.053 \\
(0.042)\end{array}$ & $\begin{array}{l}0.081 * \\
(0.044)\end{array}$ & $\begin{array}{l}0.092 * * \\
(0.043)\end{array}$ & $\begin{array}{c}0.064 \\
(0.043)\end{array}$ & $\begin{array}{c}0.083^{* *} \\
(0.040)\end{array}$ & $\begin{array}{c}0.148^{* * *} \\
(0.042)\end{array}$ & $\begin{array}{c}0.154^{* * *} \\
(0.043)\end{array}$ & $\begin{array}{l}0.092^{* *} \\
(0.044)\end{array}$ & $\begin{array}{c}0.151 * * * \\
(0.044)\end{array}$ & $\begin{array}{c}0.212^{* * *} \\
(0.059)\end{array}$ \\
\hline $\begin{array}{l}\text { log of distance to nearest } \\
\text { (big) city }\end{array}$ & $\begin{array}{c}-0.342^{* * *} \\
(0.060)\end{array}$ & $\begin{array}{c}-0.347 * * * \\
(0.060)\end{array}$ & $\begin{array}{c}-0.351 * * * \\
(0.060)\end{array}$ & $\begin{array}{l}-0.333^{* * *} \\
(0.059)\end{array}$ & $\begin{array}{c}-0.299 * * * \\
(0.055)\end{array}$ & $\begin{array}{c}-0.304 * * * \\
(0.053)\end{array}$ & $\begin{array}{c}-0.295^{* * *} \\
(0.055)\end{array}$ & $\begin{array}{c}-0.350^{* * *} \\
(0.062)\end{array}$ & $\begin{array}{l}-0.279 * * * \\
(0.059)\end{array}$ & $\begin{array}{c}-0.230 * * * \\
(0.047)\end{array}$ \\
\hline $\begin{array}{l}\text { log of average income } \\
\text { of hunters }\end{array}$ & $\begin{array}{l}-1.418^{* * *} \\
(0.444)\end{array}$ & $\begin{array}{c}-1.521 * * * \\
(0.454)\end{array}$ & $\begin{array}{c}-1.532^{* * *} \\
(0.448)\end{array}$ & $\begin{array}{c}-1.386 * * * \\
(0.437)\end{array}$ & $\begin{array}{c}-1.174 * * * \\
(0.404)\end{array}$ & $\begin{array}{c}-1.446 * * * \\
(0.397)\end{array}$ & $\begin{array}{c}-1.390^{* * *} \\
(0.416)\end{array}$ & $\begin{array}{c}-1.529 * * * \\
(0.465)\end{array}$ & $\begin{array}{c}-1.271 * * * \\
(0.444)\end{array}$ & $\begin{array}{c}-1.092^{* * *} \\
(0.414)\end{array}$ \\
\hline Log of no. of hunters in group & $\begin{array}{c}-0.141 * * * \\
(0.042)\end{array}$ & $\begin{array}{c}-0.138^{* * *} \\
(0.041)\end{array}$ & $\begin{array}{c}-0.138^{* * *} \\
(0.040)\end{array}$ & $\begin{array}{c}-0.130 * * * \\
(0.044)\end{array}$ & $\begin{array}{c}-0.100^{* *} \\
(0.041)\end{array}$ & $\begin{array}{c}-0.104 * * \\
(0.044)\end{array}$ & $\begin{array}{c}-0.100^{* *} \\
(0.045)\end{array}$ & $\begin{array}{c}-0.138^{* * *} \\
(0.040)\end{array}$ & $\begin{array}{c}-0.090^{*} \\
(0.046)\end{array}$ & $\begin{array}{c}-0.053^{*} \\
(0.030)\end{array}$ \\
\hline Log of forest share & $\begin{array}{c}-3.106^{* * *} \\
(0.655)\end{array}$ & $\begin{array}{c}-3.377 * * * \\
(0.683)\end{array}$ & $\begin{array}{c}-3.386^{* * *} \\
(0.661)\end{array}$ & $\begin{array}{c}-3.263^{* * *} \\
(0.666)\end{array}$ & $\begin{array}{c}-3.208^{* * *} \\
(0.668)\end{array}$ & $\begin{array}{c}-2.963 * * * \\
(0.685)\end{array}$ & $\begin{array}{c}-3.064 * * * \\
(0.671)\end{array}$ & $\begin{array}{c}-3.388^{* * *} \\
(0.660)\end{array}$ & $\begin{array}{l}-2.932 * * * \\
(0.688)\end{array}$ & $\begin{array}{l}-0.206 \\
(0.205)\end{array}$ \\
\hline Log of forest share_squared & $\begin{array}{c}3.945^{* * *} \\
(0.745)\end{array}$ & $\begin{array}{c}4.255^{* * *} \\
(0.768)\end{array}$ & $\begin{array}{c}4.244 * * * \\
(0.742)\end{array}$ & $\begin{array}{c}4.136^{* * *} \\
(0.753)\end{array}$ & $\begin{array}{c}4.009 * * * \\
(0.725)\end{array}$ & $\begin{array}{c}3.628 * * * \\
(0.718)\end{array}$ & $\begin{array}{c}3.757 * * * \\
(0.701)\end{array}$ & $\begin{array}{c}4.247 * * * \\
(0.741)\end{array}$ & $\begin{array}{c}3.595^{* * *} \\
(0.719)\end{array}$ & \\
\hline No. of roe deer harvested (log) & & & & $\begin{array}{c}0.031 \\
(0.027)\end{array}$ & & & $\begin{array}{c}0.014 \\
(0.025)\end{array}$ & & $\begin{array}{c}0.032 \\
(0.029)\end{array}$ & $\begin{array}{l}-0.002 \\
(0.028)\end{array}$ \\
\hline No. of fallow deer harvested (log) & & & & & $\begin{array}{c}0.084 * * * \\
(0.018)\end{array}$ & $\begin{array}{c}0.108^{* * *} \\
(0.019)\end{array}$ & $\begin{array}{c}0.108^{* * *} \\
(0.018)\end{array}$ & & $\begin{array}{c}0.124^{* * *} \\
(0.023)\end{array}$ & $\begin{array}{c}0.121 * * * \\
(0.024)\end{array}$ \\
\hline No. of wild boar harvested (log) & & & & & & & $\begin{array}{l}-0.007 \\
(0.010)\end{array}$ & $\begin{array}{l}-0.001 \\
(0.011)\end{array}$ & $\begin{array}{l}-0.009 \\
(0.010)\end{array}$ & $\begin{array}{l}-0.003 \\
(0.012)\end{array}$ \\
\hline No. of moose harvested (log) & & & & & & $\begin{array}{c}0.102^{* * *} \\
(0.026)\end{array}$ & $\begin{array}{c}0.099 * * * \\
(0.026)\end{array}$ & & $\begin{array}{c}0.110^{* * *} \\
(0.028)\end{array}$ & $\begin{array}{c}0.117 * * * \\
(0.031)\end{array}$ \\
\hline $\begin{array}{l}\text { Game diversity index } \\
\text { (all animals) }\end{array}$ & & $\begin{array}{l}0.140^{*} \\
(0.084)\end{array}$ & & & & & & & $\begin{array}{l}-0.114 \\
(0.104)\end{array}$ & \\
\hline $\begin{array}{l}\text { Game diversity index } \\
\text { (excl. wild boar) }\end{array}$ & & & $\begin{array}{c}0.255^{* *} \\
(0.111) \\
\end{array}$ & & & & & $\begin{array}{c}0.255^{* *} \\
(0.112) \\
\end{array}$ & & \\
\hline Constant & $\begin{array}{c}14.424^{* * *} \\
(2.590)\end{array}$ & $\begin{array}{c}15.016^{* * *} \\
(2.654)\end{array}$ & $\begin{array}{l}15.094 * * * \\
(2.619)\end{array}$ & $\begin{array}{c}14.304^{* * *} \\
(2.559)\end{array}$ & $\begin{array}{c}13.052^{* * *} \\
(2.344)\end{array}$ & $\begin{array}{c}14.352^{* * *} \\
(2.287)\end{array}$ & $\begin{array}{c}14.087 * * * \\
(2.405)\end{array}$ & $\begin{array}{c}15.075^{* * *} \\
(2.709)\end{array}$ & $\begin{array}{c}13.420^{* * *} \\
(2.568)\end{array}$ & $\begin{array}{c}12.017 * * * \\
(2.488)\end{array}$ \\
\hline Observations & 108 & 108 & 108 & 108 & 108 & 108 & 108 & 108 & 108 & 108 \\
\hline R-squared & 0.431 & 0.449 & 0.461 & 0.438 & 0.503 & 0.553 & 0.556 & 0.276 & 0.562 & 0.404 \\
\hline Time Fixed Effects & Yes & Yes & Yes & Yes & Yes & Yes & Yes & Yes & Yes & Yes \\
\hline \multicolumn{11}{|l|}{ Diagnostic tests } \\
\hline Breush-Pagan test [p-value] & $0.53[0.47]$ & $0.33[0.57]$ & $0.34[0.56]$ & $0.38[0.54]$ & $1.1[0.29]$ & $0.11[0.74]$ & $0.12[0.72]$ & $0.34[0.56]$ & $0.24[0.63]$ & $1.95[0.16]$ \\
\hline
\end{tabular}

Robust standard errors in parentheses *** $\mathrm{p}<0.01$, ** $\mathrm{p}<0.05$, ${ }^{*} \mathrm{p}<0.1$ 


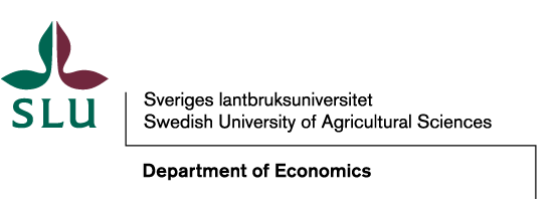

The departure towards a spatial econometric analysis of the data must be premised on a sound evidence of the presence of spatial effects in the model being analyzed. To this end, we conduct some basic diagnostic tests for spatial dependence in the lease prices using the well-known Moran's I test for spatial autocorrelation. The Moran's I statistic ranges between -1 and 1, with values between 0 and 1 signifying the presence of a positive spatial autocorrelation whiles values between -1 and 0 imply a negative spatial autocorrelation.

As shown in table 3, both statistics reveal the presence of a positive spatial autocorrelation in the OLS residuals and lease prices (dependent variable). The implication of this results is that lease prices administered in municipality $i$, is influenced among other things by the weighted average of lease prices in neighboring municipalities.

Table 3. Test for Spatial Autocorrelation

\begin{tabular}{llll}
\hline Variable & Moran I statistic & Moran I Std dev. & P-value \\
\hline OLS residuals & 0.123 & 1.67 & 0.047 \\
Dependent variable & 0.194 & 2.13 & 0.017 \\
\hline
\end{tabular}

This evidence of spatial autocorrelation in the lease prices provides some basis to proceed to estimate our hedonic price model via a spatial panel approach. It is important to stress that despite the affirmation of spatial autocorrelation in the OLS model, the significance of the spatial parameters $(\lambda$ and $\rho$ ) is important.

Results of the various model specifications estimated (SAC) unequivocally attest to the presence of significant spatial autocorrelation in both the lagged dependent variable and residuals, as represented by $\lambda$ and $\rho$ respectively. Both parameters are statistically significant and fall within the bandwidth of between -1 and 1. Implicitly, the positive spatial autoregressive lag parameter, in line with the predictions of the results in table 3, indicate that neighborhood lease prices exerts positive spillover effects within a given locality. We observe that, other things being equal, if hunting lease prices in neighboring municipalities increase by $1 \%$, lease prices in a given municipality will increase by approximately $0.3 \%$. On the other hand, the results on the spatially weighted residuals, suggest that some unobservable or omitted variables in the model that are spatially correlated have a dampening effect on lease prices. 
Table 4. Spatial-Autoregressive with Spatially Auto-correlated Errors (SAC/SARAR) Panel Model Estimates

\begin{tabular}{|c|c|c|c|c|c|c|c|c|c|c|}
\hline Variables & 1 & 2 & 3 & 4 & 5 & 6 & 7 & 8 & 9 & 10 \\
\hline \multirow[t]{2}{*}{ log of size of hunting field } & $0.091 * *$ & $0.094 * *$ & $0.098^{* *}$ & $0.087 * *$ & 0.033 & 0.057 & 0.050 & $0.095^{* *}$ & 0.031 & \\
\hline & $(0.041)$ & $(0.042)$ & $(0.042)$ & $(0.044)$ & $(0.040)$ & $(0.040)$ & $(0.043)$ & $(0.042)$ & $(0.044)$ & \\
\hline \multirow[t]{2}{*}{ Commercial/pub ownership } & 0.039 & 0.062 & 0.071 & 0.042 & 0.043 & $0.098^{*}$ & $0.106^{* *}$ & 0.076 & $0.093^{*}$ & $0.131 * *$ \\
\hline & $(0.053)$ & $(0.056)$ & $(0.056)$ & $(0.054)$ & $(0.050)$ & $(0.050)$ & $(0.052)$ & $(0.058)$ & $(0.052)$ & $(0.060)$ \\
\hline \multirow{2}{*}{$\begin{array}{l}\text { log of distance to nearest } \\
\text { (big) city }\end{array}$} & $-0.255^{* * *}$ & $-0.272 * * *$ & $-0.283 * * *$ & $-0.257 * * *$ & $-0.238^{* * *}$ & $-0.239 * * *$ & $-0.229 * * *$ & $-0.277 * * *$ & $-0.212^{* * *}$ & $-0.160 * * *$ \\
\hline & $(0.041)$ & $(0.043)$ & $(0.044)$ & $(0.043)$ & $(0.040)$ & $(0.038)$ & $(0.040)$ & $(0.044)$ & $(0.041)$ & $(0.042)$ \\
\hline \multirow{2}{*}{$\begin{array}{l}\text { log of average income } \\
\text { of hunters }\end{array}$} & $-0.969 * * *$ & $-1.118^{* * *}$ & $-1.177 * * *$ & $-0.991 * * *$ & $-0.759 * *$ & $-0.921 * * *$ & $-0.818^{* *}$ & $-1.133^{* * *}$ & $-0.671^{*}$ & -0.597 \\
\hline & $(0.368)$ & $(0.386)$ & $(0.388)$ & $(0.374)$ & $(0.354)$ & $(0.341)$ & $(0.354)$ & $(0.395)$ & $(0.361)$ & $(0.371)$ \\
\hline \multirow{2}{*}{$\begin{array}{l}\text { Log of avg. no. of hunters } \\
\text { in a group }\end{array}$} & $-0.133 * * *$ & $-0.135^{* * *}$ & $-0.139 * * *$ & $-0.132 * * *$ & $-0.092 * *$ & $-0.090 * *$ & $-0.087 * *$ & $-0.138^{* * *}$ & $-0.077 * *$ & $-0.058^{*}$ \\
\hline & $(0.039)$ & $(0.040)$ & $(0.039)$ & $(0.040)$ & $(0.038)$ & $(0.036)$ & $(0.037)$ & $(0.039)$ & $(0.037)$ & $(0.03)$ \\
\hline \multirow[t]{2}{*}{ Log of forest share } & $-2.584 * * *$ & $-2.885^{* * *}$ & $-2.960 * * *$ & $-2.656 * * *$ & $-2.878^{* * *}$ & $-2.852 * * *$ & $-2.855^{* * *}$ & $-2.953 * * *$ & $-2.713^{* * *}$ & -0.104 \\
\hline & $(0.448)$ & $(0.479)$ & $(0.479)$ & $(0.467)$ & $(0.426)$ & $(0.408)$ & $(0.422)$ & $(0.481)$ & $(0.427)$ & $(0.137)$ \\
\hline \multirow[t]{2}{*}{ Log of forest share_squared } & $3.352 * * *$ & $3.703 * * *$ & $3.782 * * *$ & $3.438 * * *$ & $3.699 * * *$ & $3.605^{* * *}$ & $3.621 * * *$ & $3.778^{* *}$ & $3.459 * * *$ & \\
\hline & $(0.582)$ & $(0.617)$ & $(0.616)$ & $(0.605)$ & $(0.553)$ & $(0.531)$ & $(0.549)$ & $(0.619)$ & $(0.552)$ & \\
\hline \multirow{2}{*}{ No. of roe deer harvested (log) } & & & & 0.008 & & & -0.003 & & 0.014 & -0.019 \\
\hline & & & & $(0.023)$ & & & $(0.021)$ & & $(0.024)$ & $(0.023)$ \\
\hline \multirow[t]{2}{*}{ No. of fallow deer harvested (log) } & & & & & $0.082^{* * *}$ & $0.108^{* * *}$ & $0.111^{* * *}$ & & $0.126 * * *$ & $0.111 * * *$ \\
\hline & & & & & $(0.019)$ & $(0.019)$ & $(0.020)$ & & $(0.022)$ & $(0.023)$ \\
\hline \multirow[t]{2}{*}{ No. of wild boar harvested (log) } & & & & & & & -0.008 & -0.004 & -0.009 & -0.004 \\
\hline & & & & & & & $(0.009)$ & $(0.010)$ & $(0.009)$ & $(0.011)$ \\
\hline \multirow{2}{*}{ No. of moose harvested (log) } & & & & & & $0.089 * * *$ & $0.085^{* * *}$ & & $0.094 * * *$ & $0.092 * *$ \\
\hline & & & & & & $(0.026)$ & $(0.026)$ & & $(0.027)$ & $(0.030)$ \\
\hline \multirow{2}{*}{$\begin{array}{l}\text { Game diversity index } \\
\text { (all animals) }\end{array}$} & & 0.093 & & & & & & & -0.109 & \\
\hline & & $(0.068)$ & & & & & & & $(0.078)$ & \\
\hline \multirow{2}{*}{$\begin{array}{l}\text { Game diversity index } \\
\text { (excl. wild boar) }\end{array}$} & & & $0.192^{* *}$ & & & & & $0.189 *$ & & \\
\hline & & & $(0.098)$ & & & & & $(0.098)$ & & \\
\hline \multirow[t]{2}{*}{$\operatorname{Lamda}(\lambda)$} & $0.373^{* * *}$ & $0.316^{* *}$ & $0.295^{* *}$ & $0.357 * * *$ & $0.264^{* *}$ & $0.225^{* *}$ & $0.239 * *$ & $0.305^{* *}$ & $0.244^{* *}$ & $0.327 * *$ \\
\hline & $(0.123)$ & $(0.140)$ & $(0.143)$ & $(0.138)$ & $(0.115)$ & $(0.106)$ & $(0.107)$ & $(0.142)$ & $(0.105)$ & $(0.151)$ \\
\hline \multirow[t]{2}{*}{ Rho $(\rho)$} & $-0.427 * * *$ & $-0.373 * *$ & $-0.345^{* *}$ & $-0.409 * *$ & $-0.425^{* * *}$ & $-0.431 * * *$ & $-0.446 * * *$ & $-0.355^{* *}$ & $-0.462 * * *$ & $-0.366^{*}$ \\
\hline & $(0.149)$ & $(0.168)$ & $(0.174)$ & $(0.167)$ & $(0.131)$ & $(0.127)$ & $(0.129)$ & $(0.173)$ & $(0.126)$ & $(0.197)$ \\
\hline Observations & 108 & 108 & 108 & 108 & 108 & 108 & 108 & 108 & 108 & 108 \\
\hline Time fixed effects & Yes & Yes & Yes & Yes & Yes & Yes & Yes & Yes & Yes & Yes \\
\hline
\end{tabular}

Standard errors in parentheses; ${ }^{* * *} \mathrm{p}<0.01,{ }^{* *} \mathrm{p}<0.05,{ }^{*} \mathrm{p}<0.1 ;$ Dependent variable: Log of lease price per annum. 
Turning our attention to the covariates, we observe some differences between results from the POLS and SAC models. The differences are largely found in the statistical significance of the regressors, as the parameter estimates are within the same neighborhood.

In line with a priori expectations, distance of hunting plot to the nearest city is shown to be inversely related to lease prices. This indicates that hunting fields located near urban centers attract higher prices relative to fields at distant locations. This is explained by the combination of high population density in urban areas, and hence high number of potential hunters, and comparatively high average income in urban centers. Thus, proximity of a hunting area to the urban centers is important as it implies relatively high demand as well as low travel cost. Similar results were obtained by Little and Berrens (2008) and Livengood (1983). Further, our results suggest that scale effects are important in lease pricing. It indicates that the total size of a field offered for lease is a positive driver of price. This is because hunting requires a relatively extensive area to increase the probability of a successful hunt, as the hunter can wait for the right time to shoot, without risking that the animal leaves the hunting area. Therefore, other things being equal, a large hunting field will attract a higher price per ha and vice versa. Again, we observe that congestion effect is a significant consideration in hunting lease pricing. Proxied by the average number hunters in a hunting group, our result shows a negative impact of hunting congestion on lease prices. Thus, even though larger hunting group have higher probability of successful hunt, at the same time it entails some cost from hunter congestion, which might be due both to the physical congestion effects at the leased land, and also a high transaction costs for reaching agreements within the hunter group on, e.g. hunting strategies and the within-group allocation of the harvest.

Interestingly, contrary to expectations that income is a positive driver of willingness to pay (WTP) for hunting leases, the results from both models suggest otherwise, showing a negative and significant impact. Thus, this suggests that people in high income municipalities pay less for their hunting lease. The underlying reason behind this result, at least within the context of our dataset, is that given that the unit of our analysis is at the municipality level, the income measure reflects the average income of residents in the municipality. This then suggest that hunting leases are relatively expensive in low income municipalities relative to high income municipalities. The reason is that most of the low income municipalities are rural communities where hunting is a popular leisure activity, reflected in, for example, a relatively larger number of hunters in these areas (Board of Agriculture, 2013) .Thus, demand for hunting in such areas is relatively high, which drives up lease prices.

Further, we find the ownership dummy to be positive and relatively significant in the various specifications. This implies that commercial/publicly owned hunting lands attract higher lease prices than privately managed land. The more precise reasons cannot be identified from our dataset, but one possible explanation is that corporate/publicly owners might let to hunters that are not privately known by them, which could motivate a higher price, as there is a higher risk for the landowner associated with the lease. 
We find a U-shape relationship between forest share and lease price, as compared to our a priori expectation of an inverted U-shape. Thus, lease prices fall with increased forest cover until a threshold is attained beyond which prices begin to rise. As evident in the various model specifications estimated via both POLS and SAC methods, the same relationship is realized. Being curious of this relationship we proceed to estimate the turning point of this relationship ${ }^{7}$. Estimate suggests a turning point of around $2.2 \%$ of forest share. This implicitly suggests a quasi linear relationship between forest shares and lease prices, given that the threshold is quite negligible. Evidence from the literature suggest that in relation to habitat quality, what really matters is not the total share of the area that is either forested or open per se, but instead, the composition of the vegetal cover. Again, even the role of the vegetal cover varies from one game species to another. For instance, lands with hardwoods are the preferred habitat for deer and other animals, compared to pine or regenerated lands (Rhyne et al., 2009). Using a hedonic price model for hunting leases in Mississippi, Rhyne et al. (2009) observe that hunters valued hardwoods significantly more than pine and regenerated stands on a prospective hunting field. Meilby et al (2006) also observe that more productive forests with higher proportions of broadleaves attract higher hunting rental prices relative to less productive forest. However, due to paucity of data on the type of vegetation in the respective hunting lands, we are unable to fully account all variations in vegetal cover in our model.

In terms of the harvest, we find similar results from both POLS and SAC models. Surprisingly, the coefficient estimates for harvest of roe deer and wild boar are insignificant in both models. The coefficients for roe deer are not consistent across models with regard to the sign. The coefficient for wild boar is consistently negative, albeit insignificant. The negative coefficient for the wild boar seems reasonable given the above observation that offer price and, potentially, bid price could be decreasing in the number of wild boar. A possible explanation for the insignificance of both could be the rapidly changing roe deer and wild boar populations, which have led to a decline in roe deer harvests by about 75\% between 1990 and 2010, and an increase in wild boar harvests from close to zero in 1990 to about 100,000 individuals in 2010, according to national bag rate statistics (viltdata.se). With rapid changes in wildlife populations, hunters and landowners may not be able to fully adapt bid and offer prices

Harvest of fallow deer and moose were significant and robust across the various specifications in the two models. This indicates that the amount of fallow deer and moose harvested are significant determinants of how much hunters are willing to pay to obtain the right to hunt on a particular piece

${ }^{7}$ For instance, consider the model: $\ln y=a+b \ln x+c(\ln x)^{2}+d \ln z$; where $\mathrm{x}$ represents forest shares and $\mathrm{z}$ for other covariate. By partial differentiation, $\frac{\partial y}{\partial x}=b\left(\frac{y}{x}\right)+2 c(\ln x)\left(\frac{y}{x}\right)=0$. Solving for $\mathrm{x}$, we obtain, $x=e^{\left(-\frac{b}{2 c}\right)}$. Juxtaposing this analogy to our empirical model, at the turning point for forest share: Fshare $=e^{\left(-\frac{\beta_{3}}{2 \beta_{4}}\right)}$ 
of land. High meat and trophy values derived from these animals could also be an added reason for this result (Mensah et al., 2015).

Next, as a test for the effect of game diversity on hunters' willingness to pay for hunting leases we include as additional covariates two diversity indices computed based on the Shannon-Weaver index approach. From the spatial model, we find the effect of the game diversity index (all animals) to be insignificant. However, after excluding wild boars from the index we significant and positive coefficient is obtained (see. Table 4). Even though we see traces of statistical significance of game diversity index (all animals) in the POLS model, it loses significance after controlling for spatial effects. Our interpretation is that this reflects the potentially negative impact of wild boar on the hunters' bid price. When the wild boar population is large, landowners are said to request increased efforts from hunters to reduce the population. Given the high opportunity cost of wild boar hunting this could imply that hunters' view the wild boar as a "bad" rather than a "good", and hence it might not be included in the basket of "wildlife goods", which is considered in game diversity index.

\section{Marginal Implicit prices}

Economic theory suggests two main values for hunting: market values (meat and revenue) and nonmarket values (recreation). Whereas the former can be determined in the market via the sale and consumption of harvest, the measurement of the latter is often done using valuation techniques such as the hedonic model. Using the estimated hedonic models, the economic value of hunting corresponds to the associated implicit prices of harvest.

In a spatial regression framework, computing implicit values requires estimating associated impact (direct, indirect and total) estimates as the coefficients in the main equation do not reflect the marginal impact of a change in the explanatory on the dependent variable ${ }^{8}$ (Anselin 1998, 2002; Anselin and Bera, 1998; Drukker, 2009). In this paper we are particularly interested in computing the direct and indirect impacts of variations in harvest of the four animals considered in the study to analyze the associated implicit prices. Further, for purposes of statistical inference, implicit values are estimated only for variables with significant ${ }^{9}$ impact estimates, i.e., direct impacts. An added reason is that the spillover effect (indirect impacts) do not necessarily reflect the preference of the hunters (Jensen et al., 2014), as hunters may not foresee the indirect effects of their bids, hence their omission in the calculation of the implicit values is justified.

${ }^{8}$ However the spatial error models (SEM) is an exception. Here, the total and direct effects coincide with the $\beta$ coefficients of the estimated models.

${ }^{9}$ As shown in table 5, only the direct impacts for fallow deer and moose harvests are significant, hence they are used to compute their respective implicit prices. 
Table 5. Impact estimates from SAC/SARAR model

\begin{tabular}{llccc}
\hline Variables & Main & Direct & Indirect & Total \\
\hline No. of roe deer harvested $(\log )$ & -0.003 & -0.002 & -0.001 & -0.003 \\
& $(0.021)$ & {$[-0.201]$} & {$[-0.183]$} & {$[-0.201]$} \\
No. of fallow deer harvested $(\log )$ & $0.111^{* * *}$ & $0.114^{* * *}$ & $0.032^{*}$ & $0.146^{* * *}$ \\
& $(0.020)$ & {$[5.677]$} & {$[1.752]$} & {$[4.410]$} \\
No. of wild boar harvested $(\log )$ & -0.008 & -0.008 & -0.002 & -0.010 \\
& $(0.009)$ & {$[-0.712]$} & {$[-0.514]$} & {$[-0.683]$} \\
No. of moose harvested $(\log )$ & $0.085^{* * *}$ & $0.087 * * *$ & 0.024 & $0.111^{* * *}$ \\
& $(0.026)$ & {$[3.104]$} & {$[1.530]$} & {$[2.800]$} \\
\hline \multicolumn{2}{l}{ Standard errors in parentheses; $[.$.$] represent Z-values; { }^{* * *} \mathrm{p}<0.01, * * \mathrm{p}<0.05,{ }^{*} \mathrm{p}<0.1$} &
\end{tabular}

Therefore using the direct impact estimates in table 5, we proceed to estimate the associated marginal implicit values for hunting one unit of fallow deer and moose (Table 6), given that they have significant direct impacts in the spatial model. As a check for robustness, we complement the results with implicit values estimated using the impact coefficients from the POLS model. The implicit prices from both models are similar albeit with some divergence. Detailed calculations are provided in table A1 in the appendix. According the our results, harvest of an additional fallow deer increases the lease price per ha by approximately between $2.48 \%$ to $2.61 \%$, whiles the same unit of moose harvest increases lease price per ha by $11.8 \%$ to $13.8 \%$.

Table 6. Implicit Prices

\begin{tabular}{lcc}
\hline \multirow{2}{*}{ Variables } & \multicolumn{2}{c}{ Implicit Prices (SEK) } \\
\cline { 2 - 3 } & SAC/SARAR & POLS \\
\hline Fallow deer & $2,689.91$ & $2,548.33$ \\
Moose & $12,145.21$ & $14,145.60$ \\
\hline
\end{tabular}

Extrapolating these estimates to the total average lease value per unit of a hunting field, we obtain the corresponding implicit values as shown in table (6). The estimates suggest that the hunting value associated with fallow deer hunting ranges between SEK 2,548 and SEK 2,689 per animal, while the corresponding value for moose is between SEK 12,145 and SEK 14,145. This indicates that hunters attach high values to moose and fallow deer hunt. Estimates on hunting value of the two game species are scanty in the literature. Available estimates on moose hunting values are provided by Boman et al., (2011). Using data from a contingent valuation survey, Boman et al., (2011) estimates the hunting value of moose in Sweden in 1987 and 2006, to be SEK 5,840 and SEK 7,035, respectively, in 2006 prices.

Comparing the moose hunting values from our study with Boman et al., (2011), requires converting the values into a common base year values. Therefore, we convert Boman et al., (2011) estimates into 2011 Swedish kronor equivalent, which corresponds to SEK 6,399 and SEK 7,708 respectively. Thus, by comparison, we observe significantly higher moose hunting values relative to estimates from Boman et al. (2011). The difference between our estimates and Boman et al.'s could be related to the 
timing of the studies, the methods employed or perhaps is an indication of an increase in hunters' valuation of moose hunting over the period. It is interesting to note that, even though economic theory suggest that economic values from stated preference approaches such as contingent valuations are higher relative to values obtained from revealed preference approaches such as the hedonic price model, evidence from a meta analyses of empirical studies on economic valuation by Carson et al. (1996) suggest otherwise. Results from their paper suggest that estimates from contingent valuations studies are, on the average, smaller than estimates from revealed preference techniques. Nonetheless, Carson et al. (1996) acknowledge that the variations in the estimate depends to an extent on the good being valued.

Finally, following from our theoretical model, endogenous land attributes such as the share of the land that is either forested or cultivated are key factors influencing the landowner's offer price for the hunting lease. Our estimates suggest that increasing the forest share of the land area by $1 \%$ at the margin increases lease prices per ha by $0.8 \%$, which translate into a marginal implicit value of SEK 823. This represents an increase in the total lease price by SEK 100 for every additional hectare of forest to the hunting field.

\section{Conclusions and Policy Implications}

This paper presents a simple model to describe the interplay between landowners and hunters in determining equilibrium hunting lease prices. The model predicts that the relative costs and benefits associated with different wildlife species are the key factors determining equilibrium lease prices. Specifically, three main conclusions were derived from the model: First, for wildlife species which yield a significant positive values to the hunter and a cost to the landowner, their impact on the lease prices, as well as the associated hunting rate, is determined by the relative cost and benefits incurred by both agents. Second, for wildlife where the damages are high but the hunting value low, our model predicts that the landowner is willing to compensate the hunter to increase harvest of the species, as long as the compensation does not exceed the cost of wildlife damages. This is then reflected in a lower lease price. Finally, for wildlife species which cause zero damage but are associated with high hunting values, both agents act as price takers with lease prices determined by the market.

Following from the predictions of our model, we proceed to analyze empirically the determinants of hunting lease prices and consequently estimate the marginal economic values associated with wildlife species using Swedish data. The analysis is conducted using spatial and non-spatial econometric techniques. The analysis reveals significant spatial spillovers in lease prices which as argued by Jensen et al. (2014), is indicative of information effect in the market. This result therefore suggest the tendency for price taking behavior in the market for hunting leases, hence the possibility of natural monopolies is minimal. Our results also show income, congestion effects, distance of hunting plots to urban centers, harvest rates and the share of forest cover on the plot as significant factors driving hunting leases prices in Sweden. Finally, our study reveal significantly higher marginal implicit prices associated with the hunting of large ungulates such as fallow deer and moose. We show that the 
respective hunting values associated with fallow deer and moose lies in the region of SEK 2,548-SEK 2,689 and SEK 12,145-SEK 14,145, respectively, per unit.

Given the large positive hunting benefits associated with large ungulates such as fallow deer and moose, their management are of significant concern from economic, ecological and social perspectives. Whereas the moose population is widely spread in the country, the fallow deer occurs in relatively few locations, and disperses slowly. Deliberate dispersal of wild species is not permitted, but potentially, the establishment of viable fallow deer populations in additional locations could be beneficial to society.

Hunting is not the only motivating factor for regulating ungulate populations in Sweden. Road traffic accidents and predator (eg. fox, lynx, and wolf) activities are also important considerations. Therefore efforts to improve conditions for large ungulate species, resulting in larger populations, could increase the frequency of traffics accident. Some of the predators, such as lynx and wolf, are subject to conservation efforts, and the simultaneous consideration of large ungulates and predators, and their respective social values, needs to be taken into account when developing wildlife policies.

Finally, we must emphasize that the issues analyzed above are not exhaustive, as other important issues that affect hunting lease prices and hunters valuation of wildlife have not been accounted for. One such issue is the biodiversity value of wildlife through its interaction with other animals and impact on vegetation and its composition. Further, we do not explicitly investigate the market structure of hunting leases, and the possible existence of market power on equilibrium lease prices. The latter is potentially important given the considerable hunting values shown in combination with the relative difficulties for new hunters without access to hunting grounds to find hunting opportunities. These are possible areas for future research. 
Department of Economics

Reference

ANSELIN, L. 1988. Spatial econometrics: methods and models, Springer.

ANSELIN, L. \& BERA, A. K. 1998. Spatial dependence in linear regression models with an introduction to spatial econometrics. Statistics Textbooks and Monographs, 155, 237-290.

BOARD OF AGRICULTURE 2013. Allt om föreningsliv och kultur på landsbygden. Jönköping- Sweden.

BOMAN, M. \& MATTSSON, L. 2012. The hunting value of game in Sweden: Have changes occurred over recent decades? Scandinavian Journal of Forest Research, 27, 669-674.

BOMAN, M., MATTSSON, L., ERICSSON, G. \& KRISTRÖM, B. 2011. Moose Hunting Values in Sweden Now and Two Decades Ago: The Swedish Hunters Revisited. Environmental and Resource Economics, $50,515-530$.

BRASINGTON, D. M. \& HITE, D. 2005. Demand for environmental quality: a spatial hedonic analysis. Regional Science and Urban Economics, 35, 57-82.

CARSON, R. T., FLORES, N. E., MARTIN, K. M. \& WRIGHT, J. L. 1996. Contingent Valuation and Revealed Preference Methodologies: Comparing the Estimates for Quasi-Public Goods. Land Economics, 72, 80-99.

CHO, S.-H., KIM, S. G. \& ROBERTS, R. K. 2010. Values of environmental landscape amenities during the 2000-2006 real estate boom and subsequent 2008 recession. Journal of Environmental Planning and Management, 54, 71-91.

CLARIN, A. W. \& KARLSSON , J. 2010. Vildsvin: Hur stora kostnader orsakar vildsvin inom jordbruket? : Jordbruksverket.

CLARK, C. W. 2010. Mathematical Bioeconomics: The mathematics of conservation Hoboken, New Jersey, USA, John Wiley \& Sons, Inc. .

CONLIN, M., DICKERT-CONLIN, S. \& PEPPER, J. 2009. The Deer Hunter: The Unintended Effects of Hunting Regulations. Review of Economics and Statistics, 91, 178-187.

DRUKKER, D. M. 2009. Analyzing spatial autoregressive models using Stata. Italian Stata Users Group meeting.

ERICSSON, G., DANELL, K., BOMAN, M., MATTSSON, L. \& WEINBERG, U. 2010. Viltet ochmänniskan. In: DANELL, K. \& BERGSTRÖM, R. (eds.) Vilt, Människa, Samhälle. Stockholm, Sweden: Liber.

FREDMAN, P., SVENSSON, B., LINDBERG, K. \& HOLMSTEDT, A. 2010. Ekonomiska värden i svenskt friluftsliv - en enkätundersökn-ing (The economic value of Swedish outdoor recreation - a questionnaire survey). Forskningsprogrammet Friluftsliv iförändring[[nl]]The Research Programme Outdoor Recreation under Change (in Swedish).

HORNE, P. \& PETÄJISTÖ, L. 2003. Preferences for Alternative Moose Management Regimes among Finnish Landowners: A Choice Experiment Approach. Land Economics, 79, 472-482.

HUSSAIN, A., MUNN, I. A., HUDSON, D. \& WEST, B. 2010. Attribute-based analysis of hunters' lease preferences. Journal of Environmental Management, 91, 2565-2571.

HÄGGMARK-SVENSSON, T., ELOFSSON, K., ENGELMANN, M. \& GREN, I.-M. 2015. A review of the literature on benefits, costs, and policies for wildlife management. In: DEPARTMENT OF ECONOMICS, S. $U$. O. A. S. (ed.) Working Paper. Uppsala.

JENSEN, C. U., PANDURO, T. E. \& LUNDHEDE, T. H. 2014. The Vindication of Don Quixote: The Impact of Noise and Visual Pollution from Wind Turbines. Land Economics, 90, 668-682.

KNOCHE, S. \& LUPI, F. 2013. Economic benefits of publicly accessible land for ruffed grouse hunters. The Journal of Wildlife Management, 77, 1294-1300.

LITTLE, J. M. \& BERRENS, R. P. 2008. The Southwestern Market for Big-Game Hunting Permits and Services: A Hedonic Pricing Analysis. Human Dimensions of Wildlife, 13, 143-157. 
eriges lantbruksuniversitet

Department of Economics

LIVENGOOD, K., R. 1983. Value of Big Game from Markets for Hunting Leases: The Hedonic Approach. Land Economics, 59, 287-291.

LUNDHEDE, T. H., JACOBSEN, J. B. \& THORSEN, B. J. 2015. A hedonic analysis of the complex hunting experience. Journal of Forest Economics, 21, 51-66.

LÖNNQVIST. 2011. Jaktens inverkan på värdet $i$ jord- och skogsbruksfastigheter [The impact of hunting on the value of agricultural and forestry land rental price]. . Bachelor Bachelor thesis, University of Gävle.

MATTSON, L., SANDBLOM, M., BOMAN, M. \& ERICSSON, G. 2008. Jakten i Sverige - Ekonomiska värden och attityder jaktåret 2005/06. Report 1, Adaptive management of wildlife and fish. Umeå, Sverige. .

MCMILLAN, M. L., REID, B. G. \& GILLEN, D. W. 1980. An extension of the hedonic approach for estimating the value of quiet. Land Economics, 315-328.

MEILBY, H., STRANGE, N., JELLESMARK THORSEN, B. \& HELLES, F. 2006. Determinants of hunting rental prices: A hedonic analysis. Scandinavian Journal of Forest Research, 21, 63-72.

MENSAH, J. T., ELOFSSON, K. \& KJELLANDER , P. 2015. Economically optimal management of two deer species competing for food. In: DEPARTMENT OF ECONOMICS, S. U. O. A. S. (ed.) Working Paper. Uppsala, Sweden.

MILLO, G. \& PIRAS, G. 2012. splm: Spatial panel data models in R. Journal of Statistical Software, 47, 1-38.

MINISTRY OF INDUSTRY 1997. Jaktens villkor - en utredning om vissa jaktfrågor [Conditions for hunting an investigation of certain hunting issues]. . In: INDUSTRY, M. O. (ed.). Stockholm.

MUNN, I., HUSSAIN, A., HUDSON, D. \& WEST, B. C. 2011. Hunter Preferences and Willingness to Pay for Hunting Leases. Forest Science 57, 189-200.

MURRAY, M. \& SIMCOS , H. 2003. The Use of Wild Living Resources in the UK - A Review

PALMQUIST, R. B. 1989. Land as a Differentiated Factor of Production: A Hedonic Model and Its Implications for Welfare Measurement. Land Economics, 65, 23-28.

RHYNE, J. D., MUNN, I. A. \& HUSSAIN, A. 2009. Hedonic Analysis of Auctioned Hunting Leases: A Case Study of Mississippi Sixteenth Section Lands. Human Dimensions of Wildlife, 14, 227-239.

ROLLINS, K., HEIGH, L. \& KANETKAR, V. 2004. Net Costs of Wildlife Damage on Private Lands. Journal of Agricultural and Resource Economics 29, 517-536.

ROSEN, S. 1974. Hedonic Prices and Implicit Markets: Product Differentiation in Pure Competition. Journal of Political Economy, 82, 34-55.

SANDSTRÖM, C., WENNBERG-DIGASPER, S. \& ÖHMAN, K. 2013. Conflict resolution through ecosystembased management: the case of Swedish moose management. International Journal of the Commons 7, 549-570.

SCHAEFER, M. B. 1957. Some considerations of population dynamics and economics in relation to the management of marine fisheries. Journal of the Fisheries Research Board of Canada, 14, 669-681.

SHANNON, C. E. \& WEAVER, W. 1949. The Mathematical Theory of Communication, Urbana, USA, University of Illions Press

STEWART, K. G. 2005. Introduction to Applied Econometrics, KY, Cengage

WON KIM, C., PHIPPS, T. T. \& ANSELIN, L. 2003. Measuring the benefits of air quality improvement: a spatial hedonic approach. Journal of Environmental Economics and Management, 45, 24-39.

YODER, J. 2000. Damage abatement and compensation programs as incentives for wildlife management on private land. Human Conflicts with Wildlife: Economic Considerations, 17-28. 
Table A1: Estimates of Implicit Prices

\begin{tabular}{|c|c|c|c|c|c|c|c|c|}
\hline & $\begin{array}{l}\text { Average } \\
\text { harvest per } \\
\text { hunting } \\
\text { group }\end{array}$ & $\begin{array}{l}\text { Average } \\
\text { Lease price } \\
\text { per ha } \\
(\mathrm{SEK})\end{array}$ & $\begin{array}{l}\text { Average total lease } \\
\text { value per land (SEK) }\end{array}$ & $\begin{array}{l}\text { Price } \\
\text { divided } \\
\text { by } \\
\text { Harvest }\end{array}$ & $\begin{array}{l}\text { Coefficient } \\
\text { estimates } \\
(\beta)\end{array}$ & $\begin{array}{l}\text { change in } \\
\text { price per ha. }\end{array}$ & $\begin{array}{l}\% \text { change in } \\
\text { price p.h. }\end{array}$ & $\begin{array}{l}\text { Change in } \\
\text { total value }\end{array}$ \\
\hline Column & $\mathrm{A}$ & $\mathrm{B}$ & $\mathrm{C}$ & $\mathrm{D}=\mathrm{B} / \mathrm{A}$ & $\mathrm{E}$ & $\mathrm{F}=\mathrm{E} * \mathrm{D}$ & $\mathrm{G}=(\mathrm{F} / \mathrm{B}) * 100$ & $\mathrm{H}=(\mathrm{G} / 100) * \mathrm{C}$ \\
\hline Game species & \multicolumn{8}{|c|}{ Estimations Based on POLS estimates } \\
\hline fallow deer & 4.36 & 124.00 & 102877.10 & 28.44 & 0.11 & 3.07 & 2.48 & 2548.33 \\
\hline moose & 0.72 & 124.00 & 102877.10 & 172.22 & 0.10 & 17.05 & 13.75 & 14145.60 \\
\hline \multicolumn{9}{|c|}{ Estimations Based on $S A C$ estimates } \\
\hline fallow deer & 4.36 & 124.00 & 102877.10 & 28.44 & 0.11 & 3.24 & 2.61 & 2689.91 \\
\hline moose & 0.72 & 124.00 & 102877.10 & 172.22 & 0.09 & 14.64 & 11.81 & 12145.21 \\
\hline
\end{tabular}

The coefficient under the $S A C$ model refers to the direct impact estimates.

\section{Computing the implicit values.}

For instance given the function: $\operatorname{Ln} P=\alpha+\beta \ln H a r v+\phi Y$, where $\mathrm{P}=$ price per ha, Harv $=$ harvest. The implicit price is computed as the partial derivative of the function with respect to harvest. This can be expressed respectively as: $\frac{\partial P}{\partial \operatorname{Harv}}=\frac{\partial e^{(\alpha+\beta \ln h a r v+\phi Y)}}{\partial \operatorname{Harv}}=\beta\left(\frac{P}{\operatorname{Harv}}\right)$

The following points relate to table A1 and must be noted.

Our dependent variable is price per ha. Meanwhile the actual value paid for a hunting area is given as the price per ha multiplied by the size of the field. From the dataset, the mean value of the hunting area is SEK 102,877 (see column c of table A1). From our regression function(s) we are able to compute for the change in the prices as a result a unit increase in harvest which is computed in columns $\mathrm{F}$ and $\mathrm{H}$. Therefore, given that implicit prices associated with each game species corresponds to the change in the value of land as a result of a unit change in the harvest. With size of the land being constant at a given time period, the change in price per ha is identical to change in toal value. Therfore we compute the implicit prices (column $\mathrm{H}$ ) by finding the value of this change in the total lease value. 


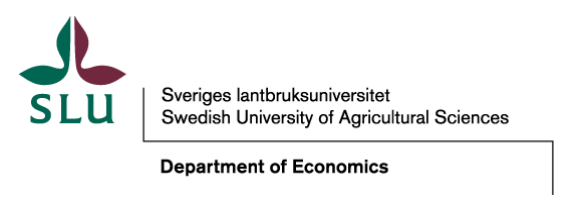

Table A2: Pairwise correlation among variables

\begin{tabular}{|c|c|c|c|c|c|c|c|c|c|c|c|c|c|}
\hline & $\begin{array}{l}\text { log of } \\
\text { price }\end{array}$ & $\begin{array}{l}\text { no of } \\
\text { hunters }\end{array}$ & $\begin{array}{l}\text { log of } \\
\text { income }\end{array}$ & ln_distance & $\ln s i z e$ & ownership & lnmoose & lnboar & lnfallow & lnroe & $\begin{array}{l}\text { diversity } \\
\text { index }\end{array}$ & lnhunters & $\begin{array}{l}\text { forest } \\
\text { share }\end{array}$ \\
\hline log of price & 1.0 & & & & & & & & & & & & \\
\hline $\begin{array}{l}\text { no of } \\
\text { hunters }\end{array}$ & -0.2 & 1.0 & & & & & & & & & & & \\
\hline $\begin{array}{l}\text { log of } \\
\text { income }\end{array}$ & 0.0 & 0.1 & 1.0 & & & & & & & & & & \\
\hline ln_distance & -0.4 & -0.1 & -0.5 & 1.0 & & & & & & & & & \\
\hline lnsize & -0.2 & 0.7 & 0.2 & 0.1 & 1.0 & & & & & & & & \\
\hline ownership & 0.0 & 0.0 & 0.0 & 0.3 & 0.1 & 1.0 & & & & & & & \\
\hline lnmoose & 0.1 & -0.1 & 0.1 & -0.1 & -0.3 & -0.3 & 1.0 & & & & & & \\
\hline lnboar & 0.0 & -0.2 & 0.0 & 0.2 & -0.1 & 0.2 & -0.2 & 1.0 & & & & & \\
\hline lnfallow & 0.3 & -0.1 & 0.1 & -0.1 & 0.1 & -0.1 & -0.3 & 0.1 & 1.0 & & & & \\
\hline lnroe & 0.0 & 0.2 & 0.2 & -0.1 & 0.4 & -0.1 & -0.2 & -0.1 & 0.3 & 1.0 & & & \\
\hline $\begin{array}{l}\text { diversity } \\
\text { index }\end{array}$ & 0.0 & 0.0 & 0.1 & -0.1 & 0.0 & -0.3 & 0.1 & -0.1 & 0.4 & 0.5 & 1.0 & & \\
\hline lnhunters & -0.3 & 0.9 & 0.1 & -0.1 & 0.7 & -0.1 & -0.1 & -0.1 & 0.0 & 0.2 & 0.1 & 1.0 & \\
\hline forest share & -0.2 & 0.2 & -0.1 & 0.3 & 0.3 & 0.2 & -0.1 & 0.0 & 0.0 & 0.0 & 0.0 & 0.3 & 1.0 \\
\hline
\end{tabular}


$d$

S LU $\mid \begin{aligned} & \text { Sveriges lantbruksuniversitet } \\ & \text { Swedish University of Agricultural Sciences }\end{aligned}$

Department of Economics 
Sveriges lantbruksuniversitet

Swedish University of Agricultural Sciences

Department of Economics

Department of Economics

Swedish University of Agricultural Sciences (SLU)

P.O. Box 7013, SE-750 07 Uppsala, Sweden

Ph. +46 186710 00, Fax+ 4618673502

www.slu.se

www.slu.se/economics
Institutionen för ekonomi

Sveriges lantbruksuniversitet

Box 7013, 75007 Uppsala

Tel. 018-67 10 00, fax 018673502 www.slu.se

www.slu.se/ekonomi 